ASEE's 123rd Annual • Conference \& Exposition • New Orleans, LA • June 26-29, 2016

We Assess What We Value: "Evidence-based" Logic and the Abandonment of "Non-Assessable" Learning Outcomes

Dr. Donna M. Riley, Virginia Tech

Donna Riley is Professor of Engineering Education at Virginia Tech. 


\title{
We Assess What We Value: \\ "Evidence-based" Logic and the Abandonment \\ of "Non-assessable" Learning Outcomes
}

\begin{abstract}
This paper seeks to analyze the recent proposed changes to ABET's baccalaureate-level programs accreditation General Criteria 3 (Student Outcomes) and 5 (Curriculum) in light of two problematic ideologies at work in engineering education: an over-reliance on Outcomes-Based Education (OBE) and an emphasis on "evidence-based" research and practice, where "evidence" is narrowly defined following the medical model of randomized controlled trials (RCTs), nearly impossible to execute validly in educational settings. The changes remove or weaken requirements for educational breadth, including global and social context, engineering ethics, and lifelong learning.

One of the stated rationales for these changes is that some outcomes are difficult to assess. To the contrary, the engineering education community has invested a great deal of time and effort innovating assessment methods to create increasingly valid, concise, and easy to implement tools for exactly this purpose. This reveals not only a "research to practice" gap in which ABET leadership may not be aware of these advancements, but also an epistemic gap where "evidencebased" logic has all but eliminated some of the most effective tools we have in educational assessment.

This immediate crisis is brought on by our own commitment to Outcomes-Based Education. It is this obsession that leads to the logic under which, even if student outcomes were difficult to assess, that this would somehow constitute grounds for their elimination. Ultimately, we assess what we value; and we have come to value measurability of outcomes over student learning. We ask "what works" rather than what is appropriate for engineers to learn entering the profession in the $21^{\text {st }}$ century.

This paper calls for members of the Liberal Education/Engineering and Society Division to recount our history as advocates for educational breadth, and redouble our efforts for the long haul. The Division is well positioned to serve as a clearinghouse of information with convening power for building coalitions across ASEE Divisions and even across professional societies comprising ABET's membership, to rebuild consensus around the vision of a broadly educated engineer in 2020 and beyond.
\end{abstract}

\section{Introduction}

At ASEE's 2012 Annual Meeting, the Liberal Education/Engineering and Society (LEES) Division held a special session on "Accreditation and Outcomes-Based Education." In it, several authors critiqued the historical and present-day structures of educational standards in engineering, both in the United States and abroad. At the 2015 Annual Meeting in Seattle, attendees were shocked to discover that, beginning in 2009, members of ABET's Engineering Accreditation Commission (EAC) had been meeting to eliminate a number of educational 
outcomes from baccalaureate-level programs General Criterion 3, specifically those that deal with professional skills, including social and global context, contemporary issues, professional responsibility, and lifelong learning (see Appendix). While the process has been exceedingly opaque, it appears that the move came following feedback from ABET evaluators, who are rarely trained in assessment, that these outcomes were too hard to assess, and therefore ought to be eliminated.

In this paper, I argue that this immediate crisis in engineering education is the logical result of an outcomes-based approach ${ }^{1}$ : if what we value is assessable outcomes, then anything that appears difficult to assess (whether or not it is actually difficult to assess) will be devalued, and will ultimately drop off our list of educational goals. In an outcomes-based regime, it is no longer important which stakeholders value the outcomes; we have lost sight of the larger conversation, documented in so many blue ribbon reports, about what engineering education ought to achieve for students. The 2020 vision of the broadly educated engineer is lost in the nitty-gritty of what is quantifiable.

This points to a second contributor to the present crisis: our own community's move toward "rigorous engineering education research" and "evidence based practice." ${ }^{2}$ What we have chosen to consider measurable is only that which fits one narrow epistemic framework for evidence. Implicit in this move is a devaluing of the epistemic frames upon which the eliminated outcomes are based; global and social context, professional responsibility, and lifelong learning are not easily or fully characterizable within empirical and logical positivist ways of knowing. We need multiple epistemic frames both for our students to meet the full set of engineering learning outcomes, and to adequately assess student achievement of them.

Taking the long view, advocates for liberal education have struggled for the broad education of engineers for decades, and we will continue to be in this struggle for the long haul. Now is the time for us (once again) to organize, to build coalitions, and to leverage all of our social analytical ability toward the effort of winning hearts and minds in support of the broad education of engineers. What appeared to be consensus over EC2000 is now revealed to have been fragile at best, and we must work to strengthen and re-build this movement. I propose several ways in which the LEES Division can act as a clearinghouse with convening power to build coalitions across those who advocate for liberal education of engineers, across ASEE divisions, and across the broader set of professional engineering societies, which comprise the membership of ABET.

Calls for advocacy may seem out of place to some in the engineering education research community, or inappropriate (lacking rigor) for a conference paper such as this. We are a community focused on improving engineering education, producing widespread and systemic change. We are not interested in change for change's sake, but rather concerned with the particularities of how and what engineering education should be. At this moment, new ABET criteria are poised to re-set norms for the profession and for the practice of engineering formation. We must engage the process on those terms. It must be the work of engineering education research to speak directly to the situation, absolutely in a scholarly manner, vigorously informed by the literature, as I seek to do here. But a scholarship of change, if it is to have any integrity, cannot feign neutrality. 
After describing the revision process for the ABET criteria to date and ABET's stated rationale for the changes, I provide a detailed analysis of the proposed new outcomes, with particular emphasis on the changes to engineering ethics and social context. Following this discussion I provide analysis of the changes in light of the current trends in outcomes-based assessment and evidence-based engineering education research. I close with recommendations for the long-haul efforts of the LEES Division to rebuild support for broadly educated engineers.

\section{A Brief History of ABET's Accreditation Criteria Revision Process}

ABET's EC 2000 criteria $^{3}$ were developed over a decade-long process ${ }^{4}$ that engaged stakeholders from across industry and academia. In 1992, ABET President John Prados ${ }^{5}$ called for a paradigm shift in engineering education, noting that while the post-war paradigm shift to engineering science was sorely needed to meet the technological challenges of the day, it left engineers unprepared for the present-day needs of industry:

Few would argue that the engineering science emphasis has not produced graduates with strong technical skills. However, these graduates are not nearly so well prepared in other skills needed for success in today's engineering practice and in the development and management of innovative technology; these include: (1) oral and written communication, (2) ability to work effectively as a member of a team, and (3) understanding of the external forces that exert a profound impact on both engineering and business decisions. Among these forces are economic constraints, social and environmental impact, safety and health responsibility, political pressures, ethics, and the general contrariness of human nature. $(2)^{5}$

Prados, working collaboratively with the next ABET president Al Kersich, co-appointed members of the Committee to Review ABET Accreditation Procedures, which began what would be an eight-year process ultimately culminating in the rollout of EC 2000. Prados fully recognized the challenges EC 2000 would pose, challenges that appear now to have come home to roost:

But is such an approach [to engineering education] realistic given the background of our present faculty and the financial pressures that force most large engineering schools to depend heavily on outside research funding to keep their doors open? Am I describing an impossible dream? Can one structure an engineering education about practice-oriented team experiences without depriving students of needed analytical skills and knowledge of the engineering sciences? Can one find enough engineering faculty with the interest and capability to develop case studies at appropriate levels, along with supporting instructional modules? Will industry be willing to devote the financial and human resources needed to work with faculty in developing and conducting case studies? Will enough faculty be willing to forego their ego-stroking authority as lecturers and become coaches instead? Even if faculty are willing, can deans and department chairs allow them to devote so much of their time to efforts that are not likely to bring in extramural funds? AND FINALLY, WOULD ABET EVER ACCREDIT SUCH NON-TRADITIONAL 


\section{PROGRAMS, WHERE COUNTING THE BEANS MIGHT BE DIFFICULT, IF NOT IMPOSSIBLE? $(3)^{5}$ [emphasis in original]}

Compared to the accreditation revision process currently underway, the EC 2000 process was far more careful, deliberate, and transparent, involving many different stakeholder groups. While the letter from Prados was widely circulated in its time in the early 1990s, even with the ease of Web 2.0 it is impossible to find a clean articulation of ABET's rationale for accreditation revisions at the time the current EAC committee began its deliberations in $2009 .{ }^{6}$

Indeed, Prados was not the first to call for broad education of engineers, and knew he was building on a century of blue ribbon reports (including The Mann Report, The Wickenden Report, Engineering Education after the War, and The Grinter Report) $)^{7,8,9,10}$ emphasizing the need for educational breadth in engineering formation. This consensus has only grown since, with reports such as the Engineer of $2020,{ }^{11}$ Educating the Engineer of 2020, ${ }^{12}$ and the more recent three-part TUEE ${ }^{13}$ study from ASEE). The global accreditation community has affirmed the importance of educational breadth, in multiple agreements including the Washington Accord, the Sydney Accord, and the Dublin Accord. ${ }^{14}$ Engineering historian Bruce Seely has noted the cyclical nature of these calls. ${ }^{15}$

An ABET-funded study on the impact of EC 2000 by Lisa Lattuca and colleagues at the Center for the Study of Higher Education at Penn State ${ }^{16}$ found that $75 \%$ of the approximately 150 chairs surveyed reported "some" or "significant" increases in emphasis on communication, teamwork, use of modern engineering tools, technical writing, lifelong learning, and engineering design, without significantly impacting technical outcomes. More than half the faculty reported similar gains in these areas in their regularly offered courses. The 2004 graduates surveyed reported feeling better prepared in all areas assessed compared with their counterparts from the class of 1994, with the largest gains located in understanding of societal and global issues, the ability to apply engineering skills, teamwork, and the appreciation of ethics and professional issues. I have elsewhere argued that transformative gains from EC 2000 are necessarily constrained by the outcomes-centered approach, ${ }^{1}$ but it is crucial to note that ABET's own commissioned study declared EC 2000 an unequivocal success:

In the 1980s, employers expressed dissatisfaction with engineering graduates' professional skills. By the mid-1990s, ABET had implemented a new accreditation philosophy based on assessments of student learning and continuous improvement principles. Today, according to the accumulated evidence in Engineering Change, engineering education in the United States has changed dramatically. Engineering programs and faculty members have reengineered their curricula, teaching methods, professional development practices, program assessment and decision making, and, to some extent, their hiring, promotion, and tenure criteria.

Perhaps most important, graduates in 2004 were measurably better prepared than their counterparts of a decade ago in all of the nine learning areas assessed. The greatest increases were in understanding of societal and global issues, the ability to apply engineering skills, teamwork, and the appreciation of ethics and 
professional issues - all attributes U.S. engineers need to compete successfully in a competitive, global economy. ${ }^{16}$

It is truly puzzling that within three years of the publication of this study, ABET would begin the process of reversing all this progress.

It is difficult to trace what happened next, because scant information is available. However, according to slides available on ABET's website during the first comment period in 2014-2015, ${ }^{6}$ a committee was formed in 2009 to begin a process of revision to Criteria 3 and 5. Suggested changes were rolled out in July 2014, with a comment period ending in May 2015 (see Appendix). At an Ethics Division session at the June 2015 ASEE meeting in Seattle, during a broad discussion about engineering and peace, some Division members brought up the ABET changes. The author was serving as NSF Program Officer for Engineering Education at the time, and this was the first I had heard of it. It was also news to my boss, and my boss's boss, who was the head of the Engineering Directorate at NSF. As the conference unfolded, it became clear that most if not all of the ASEE leadership was also unaware of the proposed changes.

In response to ABET's revelation of the proposed accreditation revisions, ASEE's leadership went into high gear. As individuals learned (in June) that the EAC would be voting in early July 2015 on the proposed changes, two strategies unfolded. First, 346 engineering educators, including 99 deans and associate deans, wrote to request that the timeline for the first comment period (June 2014 - June 2015) be extended so that more stakeholders in the community could consider the proposed changes and offer feedback. ${ }^{17}$ Second, individuals and ASEE divisions and committees wrote to express their concerns and, for some, grave misgivings about the changes. The LEES Division wrote in defense of the need for engineers to be broadly educatedspecifically requesting ABET not cut as assessed outcomes the abilities to understand professional responsibility, to understand the historical and contemporary social contexts of their work, to engage across disciplines in teamwork, to design for a variety of specific objectives and constraints, and to engage in lifelong learning. ${ }^{18}$ Additionally, LEES implored ABET to add an outcome recognizing the importance of the capacity of engineering professionals to meaningfully incorporate ideas from diverse groups in defining engineering challenges, meaningfully engage the participation of all groups in engineering practice, and equitably address impacts of engineering on all groups. The Ethics Division registered concurrence with the LEES letter. ${ }^{19}$ The Technological and Engineering Literacy and Philosophy of Engineering (TELPhE) Division additionally raised the concern that the proposed changes could "undermine the historical conception of engineering as a profession." ${ }^{20}$ In a separate action, the Diversity Committee of ASEE noted that "many critical core values and skills essential to the engineering profession are not expressed in the proposed outcomes." 21

Following this outcry from ASEE members and others, the proposed changes were altered slightly and a new version was released in November $2015 .^{22}$ With this new version came a new rationale for making the changes, different from the arguments presented in the slides from the 2014-15 comment period, as well as a new description of the change process. The new articulation claimed that the EAC identified a broad range of stakeholders and conducted outreach with those groups. However, the specific descriptions of outreach principally involved only ABET entities: 
These outreach efforts included presentations to both the ABET Industrial Advisory Committee and the ABET Academic Advisory Committee in 2013 and 2015, along with presentations by ABET staff at several professional society meetings in 2014 and 2015. In addition, a link on the ABET website was established so that constituents could provide comments directly. At the request of the task force, the EAC also surveyed program evaluators during the 2010-11 cycle regarding the elements of Criterion 3 that led to citations of shortcoming. ${ }^{23}$

As noted above, the presentation by ABET staff to ASEE occurred for the first time at ASEE 2015, in June, at the very end of the comment period. While a web form (not a separate website) was created for constituent comments, the URL for accessing the form was not easily accessible from the ABET website's main page, requiring one to "drill down." This essentially ensured one had to know what one was looking for in order to find it. Nothing of the revision process had been made known widely to ASEE's membership, and it appeared from conversations with members of IEEE and ASME that their experience was similar. Whatever the outreach strategy had been, it had clearly failed to reach not only rank-and-file members of professional societies, but also societies' leadership as well as the officials at NSF and NAE most closely involved with engineering education initiatives. Especially alarming was that the author spent time on several occasions in meetings with ABET staff discussing the need to change ABET accreditation criteria. These occurred at separate meetings on the topics of engineering and liberal education; brainstorming new approaches for addressing social inequality in engineering; access for veterans to engineering; and women's participation in engineering. At no time in these meetings did ABET staff members who were present mention that ABET was actively in the process of revising its accreditation criteria or that an open comment period in response to such revision suggestions was underway.

\section{Rationale for Changes}

As part of the opaque 2014-15 communication process described above, ABET presented a set of slides ${ }^{6}$ stating two main reasons for changing Criteria 3 and 5:

- A belief that it is difficult to assess certain outcomes, and that this results in inconsistency in evaluation of programs;

- A belief that having a large number of specified outcomes was making educational innovation impossible.

By November 2015, a new rationale posted on ABET's website ${ }^{23}$ claimed that the Criterion 3 Student Outcomes were not current, measurable, or realistic, and that most program shortcomings fell in this area. All these claims were unsubstantiated in that no evidence was presented to support them. Contrary to ABET's claim, these required assessments have driven vibrant areas of research in engineering education assessment to ensure that all outcomes are assessable in ways that are as straightforward and efficient as possible. ${ }^{24,25,26,27,28,29,30}$ ABET's own Gloria Rogers held annual workshops to support the engineering community in learning how to assess all EC 2000 outcomes. ${ }^{31}$ Moreover, as will be shown below, the changes collapse multiple disparate items to be assessed into single outcomes, in violation of best practices in assessment, making the new criteria harder to assess by any measure, and not, in point of fact, any shorter or less burdensome on assessors. ${ }^{32}$ The changes do not open up room for innovation; 
according to ABET's own 2014-15 slides, programs tend to do the bare minimum necessary to address assessment requirements. ${ }^{6}$ The notion that suddenly programs will innovate under the new criteria, with all the other pressures faculty are under in higher education today, is frankly absurd. It contradicts a careful study of four institutions constrained in terms of educational innovation by accreditation, not because the process itself was cumbersome, but because of the norms and constraints imposed by ABET evaluators and the broader engineering culture. ${ }^{33}$

Because ABET relies strongly on "old-boy networks" - exclusive relationships of mutual support and influence - to select leadership from Program Evaluators on up, the decision-making structure has a pronounced problem of underrepresentation (even by engineering standards) of women, people of color, and younger engineers. Have any ABET evaluators been educated under EC 2000? How many have a true appreciation for professional skills? How many have spent careers focused narrowly in technical research areas that do not lend themselves to understanding assessment, or to thinking in non-quantitative ways about student learning and its assessment? Perhaps evaluators have stopped counting beans (i.e., credit hour distributions), but many couldn't stop counting, ever looking for the quantitative assessment, oblivious to the sociological truism that "not everything that counts can be counted, and not everything that can be counted counts." 34

\section{What's Changing with ABET?}

Having described the process and rationale for the criteria changes (as best I have been able to understand them as a rank-and-file member of the ASEE, without any special access to ABET's deliberations), I turn now to the substance of the proposed changes. Table 1 shows succinctly what is changing with ABET's Criteria 3 and 5.

Arguably the most significant change is the removal of the phrase "adequate attention and time" from Criterion 5. This Criterion lays out three main components of an engineering curriculum: math and science courses (for which one year is specified); engineering content (for which at least one and one-half years are specified); and educational breadth (for which no minimum is specified). Atsushi Akera ${ }^{35}$ has noted that in 1956, the Engineers' Council for Professional Development (ECPD), ABET's precursor, answered the call of the many blue ribbon reports ${ }^{7-10}$ and began requiring a full year of humanities and social science courses as part of engineering curricula. This requirement was weakened decades later to allow as little as half a year. When EC 2000 abandoned credit-hour bean counting, the language shifted to require "adequate attention and time" for general education subjects (while retaining numerical requirements of a year for fundamental science and math courses and a year and a half of engineering content). Nevertheless, regardless of whether one casts EC 2000's advancements for liberal education of engineers as meager, incremental, or transformative, there is no doubt that the current proposed changes, by omitting the requirement of "adequate attention and time" for educational breadth, drops the floor on well-rounded education of engineers. This change threatens to send the country back not just 20 years to the 1990s before EC 2000, but more than 60 years, to the time before ECPD required a year of humanities and social sciences. 
ABET representatives have pointed to their lofty preamble language as a vehicle for producing broadly educated engineers (with language around multicultural competencies added in the latest round), yet they refuse to put their money where their mouth is by specifying even minimal requirements for educational breadth, or by including critical professional skills such as negotiating difference, power, and privilege as student outcomes upon which programs will ultimately be assessed and curricula designed.

Table 1. Summary of Proposed Changes to ABET's Criteria 3 and 5

\begin{tabular}{|c|c|}
\hline \multirow[t]{7}{*}{ ENTIRELY REMOVED } & "adequate attention and time" for educational breadth (Criterion 5) \\
\hline & Knowledge of contemporary issues $(3 \mathrm{j})$ \\
\hline & "realistic" constraints $(3 \mathrm{c})$ \\
\hline & Multidisciplinary (3d) \\
\hline & Lifelong learning (now information literacy; not the same thing) (3i) \\
\hline & Political (now policy; not the same thing) (3c) \\
\hline & Social (now only societal; not the same thing) (3c) \\
\hline \multirow{3}{*}{$\begin{array}{l}\text { DEMOTED TO } \\
\text { PREAMBLE }\end{array}$} & Manufacturability (3c) \\
\hline & Sustainability (3c) \\
\hline & Health and safety $(3 c)$ \\
\hline \multirow[t]{2}{*}{$\begin{array}{l}\text { DILUTED/LUMPED } \\
\text { TOGETHER }\end{array}$} & $\begin{array}{l}\text { Ethics, professional responsibility, global, societal, environmental, } \\
\text { economic }(3 \mathrm{~h}, 3 \mathrm{f})\end{array}$ \\
\hline & $\begin{array}{l}\text { Teamwork, goal-setting, task management; risk analysis; uncertainty } \\
\text { analysis (3d, new items) }\end{array}$ \\
\hline
\end{tabular}

The abandonment of the outcome around knowledge of contemporary issues, paired with the deletion of the word "realistic" as a modifier for the constraints under which engineers design, is curious indeed. It is as if ABET wishes the profession to turn away from the here and now, from that which is, well, real. Surely one of those realities is the multi-, inter-, and transdisciplinary nature of engineered systems and engineering work today. To no longer require that engineers have the ability to bridge disciplinary divides does not bode well for our nation's transportation systems, energy systems, telecommunications, pharmaceuticals, environmental protection, and so much more. The inability of engineers to consider the human factor is already the cause of disasters too numerous to mention. ${ }^{36,37}$

Lifelong learning has been removed, and replaced with information literacy: "an ability to recognize the ongoing need for additional knowledge and locate, evaluate, integrate, and apply this knowledge appropriately." It is troubling indeed that the EAC committee seems to treat knowledge as if it were mere information: something to be located, evaluated, integrated, and applied. It is even more troubling that they seem to think knowledge acquisition (and worse 
information acquisition) is equivalent to learning. This is not to denigrate information literacy, which is vital; however, it is only necessary but not sufficient. Knowledge encompasses higher order, meta-level components such as epistemology, or the frameworks shaping how we know what we know. ABET's narrowing of what knowledge is leaves out the role of epistemology, as well as of beliefs, of intuition, of emotion, and of experience. It ignores the ways knowledge is contextually situated within disciplines, communities, cultures. It also ignores the ways in which knowledge is power, that structural power relations determine what is held as known, or as true. ${ }^{38}$ Information literacy misses the critical insight that knowledge is social and hence contested.

ABET's conception of learning as knowledge/information acquisition leaves no room for the building of the intellectual power that comes through experience and reflection, ${ }^{39}$ through encountering different ways of knowing. There is no room for critical thinking and reflective action. ${ }^{40}$ Most important, lifelong learning is foremost about a love of and passion for learning itself, rather than focusing exclusively on the discrete knowledge that is acquired. As Dewey wrote "The most important attitude that can be formed is that of desire to go on learning. If impetus in this direction is weakened instead of being intensified, something much more than mere lack of preparation takes place" (48). ${ }^{41}$ With these reductionist misconceptions about knowledge and learning, it is clear that a concept like lifelong learning didn't stand a chance.

Many of these omissions are in fact related - one needs contemporary issues and realism for the relevance that produces passion to learn. One needs multidisciplinarity and educational breadth to develop intellectual power and critical thinking. ${ }^{42}$

Perhaps the most unsurprising change to Criterion 3 is the removal of the word "political" and its replacement with the more palatable idea "policy." Of course the two are not interchangeable. Political processes produce, enact, sustain, mediate, and change policies. ${ }^{43}$ Political is the broader term, encompassing policy-making processes. By shifting to the term policy instead of political, ABET is shrinking the intended domain of action for engineers. Understanding the political contexts that give rise to engineering projects, and analyzing potential political implications is an essential professional capacity. The political nature of engineered systems has been well explicated in the field of science and technology studies. ${ }^{44,45}$ More recently Erin Cech and Heidi Sherick ${ }^{46}$ have explored the tendency of the profession to actively deny this reality-a phenomenon they label depoliticization. At the heart of this phenomenon lies both a false duality engineers maintain between the technical and the social (including political), and a pretense toward logical positivist epistemology that is, in the end, insufficient for engineering practice.

The elimination of the need to consider social constraints, with all consideration of social concerns reduced to "societal contexts" only, constitutes a similar narrowing of scope. Social interactions constitute the full range of human connections with others and occur across all kinds and sizes of groups and networks with different types of organizational structure. ${ }^{47}$ Informal interpersonal interaction, design teams, engineering firms, departments of public works, the Army Corps of Engineers, universities, and the engineering profession are all examples of different kinds of social groups directly relevant to engineering practice, none of which are rightly termed "societal contexts." When scholars of Science and Technology Studies consider the social contexts of engineering, they extend far beyond societal and public policy contexts; 
they also consider users of specific technologies, community groups, families, specific demographic groups such as women of color, people with disabilities, or children, and many more arrangements of people. In addition to social groups such as these, engineers also need to understand the operation of social constructions, the social processes that largely determine the meaning we assign to processes, behaviors, and even material objects - everything from attributes such as gender, class, and intelligence to technology itself. Restricting considerations to the societal level implies that engineers need not bother to understand the myriad smaller arrangements of people as they intersect with engineering practice: the specific context of a group of clients or users, a particular cultural group affected by a project, the organizations with which a project is developed, or the social constructs and cultural phenomena shaping what is prioritized and why in any of these settings.

The removal of health and safety from the accreditation criteria may result in engineers defaulting on our first ethical duty. While the ethics outcome, discussed further below, may ensure that engineers know they must "hold paramount the health, safety, and welfare of the public," 48 by demoting health and safety to the preamble of Criterion 3 , there is no assurance that engineers will have any measurable abilities to enact protections of the public's health and safety (not to mention its welfare).

The relegation of manufacturability to the preamble appears a direct slight to a presidential administration that has overseen a renaissance in manufacturing in the United States through advanced and additive manufacturing as well as the emergence of Maker culture. To devalue these specific abilities in high demand in the new manufacturing economy is to cut our nose off to spite our face.

The word sustainability has been removed and environmental contexts presumably left to cover for it. But there are multiple dimensions of sustainability (e.g., the classically identified "three pillars" are economic, environmental, and social), ${ }^{49}$ and the term has gained traction because it puts the tensions among competing forces into play. To speak only of environmental sustainability again reduces the engineering professional's required scope of analysis and areas of competency.

\section{Ethics and Social Context}

The clear theme across the omitted and demoted items above is ABET's apparent discomfort with educational breadth generally, and with the social and political in particular. Nowhere is this more evident than in the revision journey of Student Outcomes 3(f) and 3(h) - the ones dealing with ethics and social context. In the first draft of the changes, 3(h) was eliminated from Criterion 3 entirely ("the broad education necessary to understand the impact of engineering solutions in a global, economic, environmental, and societal context"). In 3(f) the phrase "professional responsibility" was dropped and an understanding of "ethics and professional responsibility" became "demonstrate ethical principles," alarming many in the ethics community. Already many engineers conflate personal morality and professional responsibility, such that our textbooks must cleanly address the distinction. ${ }^{48}$ Removing the professional context in which engineering ethics is necessarily practiced and replacing it with the word "principles" evokes 
personal morality (as in, “Does one, or doesn't one, have principles?"). This change is certain to confuse the issue, at best. Relegating educational breadth to Criterion 5, where students need not demonstrate their capacities in this regard, drew concerned comments from many members of the community.

In what may have been an attempt to address both concerns, the most recently proposed changes to Criterion 3 now dilute professional ethics in an everything-but-the-kitchen-sink outcome where ethics is conflated with measures of intercultural competencies, economic evaluations, environmental assessments, and social analysis. This move more than any other reveals that ABET leadership is incapable of or not interested in distinguishing among the very different skill sets involved in these separate professional competencies. The phrasing of this outcome implies that engineers need only consider social impacts when making informed judgments about ethics: "An ability to recognize ethical and professional responsibilities in engineering situations and make informed judgments, which must consider the impact of engineering solutions in global, economic, environmental, and societal contexts."

This is no time to be turning back the clock. As underscored by the crises in professional ethics among engineers at Volkswagen AG, the US Newmont Mining Corporation, and Michigan's Department of Environmental Quality - only three of the latest in a long series of crises in which engineers blatantly disregard the health, safety, and welfare of the public - there is need for explicit and meaningful education in ethics and professional responsibility as an unadulterated learning outcome, as well as the explicit operationalization of health and safety considerations in engineering practice. ${ }^{50,51,52}$

The use of the word "impact", which was also a problem in EC 2000, raises another set of concerns. Impact evokes a linear technological determinism in which engineers act in an apolitical, asocial, ahistorical setting, as if problems are pre-defined for them (in a vacuum) and they must then worry about the impacts their designs will have in particular contexts. Contrary to this simplified version of impact, the reality is that engineering projects emerge from and within social contexts that must first be understood if any meaningful attention is to be directed to impacts. Technology and society are mutually shaped through a process of co-construction; engineering is already social, political, global, and so on. ${ }^{53}$

ABET representatives have repeatedly denied that they are removing essential elements from the learning outcomes, articulating a "Prego" defense (claiming, like the canned spaghetti sauce purported to be as good as homemade, "it's in there"). Perhaps ABET does not realize that disappearing "global, economic, environmental, and societal context" first as "design under multiple constraints," then in the most recent version subordinating it to the limited consideration of ethical impacts, reveals that they do not understand the meaning or value of "a broad education" and how this breadth might require consideration of context beyond specific narrow acts of engineering practice.

The proposed changes in both versions inexplicably weaken or eliminate many of the professional skills industry clearly values. The result of this will surely be a deprofessionalization of engineers, a loss in status and stature for the profession, and a shrinking of the scope of engineers' responsibilities in the workplace and in society. 
As a practical consideration, there is a high likelihood that in many institutions, the newly proposed Student Outcomes 4, 5, and 7 (addressing communication, ethics/social context, and teaming/project management, respectively) will all be relegated to capstone courses, perhaps with a cursory introduction in the first year, but with little or no emphasis in the middle years. Our community knows this is a "worst practice," as many scholars have been building ethics across the curriculum, communication across the curriculum, and design across the curriculum efforts for decades. ${ }^{54,55,56}$ The ways in which these disparate skills are lumped together (why else would you put teaming, risk assessment, uncertainty analysis, and project management together, unless you assumed they would be taught together?), pushes against the developmental approach to learning so many have struggled to build.

We assess what we value; by treating certain outcomes as expendable, ABET is making a clear statement of what it values, and it is out of sync with both industry needs and most if not all of the blue ribbon reports on engineering education in the $20^{\text {th }}$ and $21^{\text {st }}$ centuries. Organizational research shows that the results you achieve are no more and no less than what you set out to measure and reward. ${ }^{57,58}$ Engineering programs will evolve to deliver on the specific measures of success and reward articulated in the new student learning outcomes. Any assumption that in this process the 'other stuff' (i.e. broader outcomes) will somehow remain important and 'rub off' on students is woefully naïve.

\section{Outcomes-Based and Evidence-Based Thinking in ABET}

Make no mistake; we are watching an engineering disaster unfold before our very eyes. As members of the engineering education community begin to take in the full meaning and implications of the changes as described in the last section, some may be filled with a sense of bewilderment. How did this happen? Why didn't we see this coming? In some ways it is shocking that, seemingly overnight, what seemed to have been a widespread consensus around the need for broadly educated engineers has evaporated. At the same time, this is in a sense the predictable end of an outcomes-based approach, catalyzed by the inane double speak of "evidence-based" practice.

Outcomes-based education (OBE) emerged in the 1990s in the pop-educational work of Bill Spady, ${ }^{59}$ an ideological hodgepodge formed from the educational concept of mastery, the industrial management ideas of Fordism and Taylorism, the discourse of corporate jargonism, and contemporary trends around the corporatization of the university, where students are merely "customers." Critics have noted that OBE is not learner-centered as it purports to be, but is at its core outcome-centered ${ }^{60}$ Accountability is everything, and OBE relies on positivist epistemologies to produce the necessary evidence. ${ }^{1}$ This relates directly to the parallel emergence of evidence-based practice in education. Built upon the model of evidence-based medicine (EBM), which gained prominence in the 1990s, "evidence based" frameworks look to randomized controlled trials as the evidentiary gold standard. Just as EBM closes off knowledge related to social and cultural determinants of health, privileging an individualistic biomedical model of treatment effectiveness, evidence-based practice in education aspires to isolate and control conditions in order to determine "what works." 61 
David Olson, ${ }^{62}$ a critic of the evidence-based approach, begins with the observation that students are not patients, "treatments" is a misnomer, and randomized controlled trials are impossible to construct with validly. There is no such thing as a placebo, because students form - and ought to form-beliefs about their learning under different conditions, and those beliefs shape their learning. There is no such thing as a controlled dose, and confounding variables abound. Critically for the present interrogation of ABET, Olson found in following up on large-scale studies that "Treatments that on the surface may appear quite different turn out to be quite similar when they are implemented under constraints of a fixed set of goals and common criteria for achievement" (24). ${ }^{62}$

It is against this backdrop that we must read ABET's pronouncement that its own outcomes are difficult to assess and should therefore be changed or eliminated. ${ }^{6}$ First, outcomes-based logic works to subordinate and devalue considerations of process. Thus, when reports of inconsistent evaluation of certain outcomes came in, ABET chose to change the outcomes rather than examine such factors as the background and training of evaluators in assessment; the relatively traditional educational experience of most evaluators compared with the expectations of EC 2000; or the extent to which evaluators actually value the different outcomes they are attempting to assess. When universities complained about a burdensome accreditation process, rather than simplify the process (for example, by rotating outcomes of emphasis each cycle), ABET sought simply to reduce the number of outcomes.

In an outcomes-based regime, outcomes become central and crowd out other considerations. Therefore anything that appears difficult to assess (whether or not it is actually difficult to assess, and however important it may be educationally) will be devalued, and ultimately drop off our list of educational goals. In an outcomes-based regime, it is no longer important which stakeholders value the outcomes; we have lost sight of the larger conversation about what engineering education ought to achieve for students and for the profession. The 2020 vision of the broadly educated engineer is lost in the nitty-gritty of what is deemed assessable.

The second problem at work in the pronouncement that some outcomes are difficult to assess and should therefore be changed or eliminated is that it makes an overwhelming number of presumptions about assessment processes, their underlying epistemologies, their validity, and the relative difficulty of different assessment approaches. If we were to unpack this "difficult to assess" perception, what might we find? Does ABET really mean "difficult to quantify"? Have those making these pronouncements read the relevant assessment literature, where many quantitative (as well as qualitative) measures are readily available? ${ }^{24-30}$ So, what then? It comes down to values, epistemology, and power. What can we know, and how do we know it? Who has authority to determine what is and is not assessable, or what does and does not constitute evidence?

In an outcomes-based regime, the only questions worth asking are: "what works"; "did you achieve it"; and "how can you prove it?" Our field's grand concession to "evidence-based practice" in our voracious pursuit of "rigorous engineering education research" has brought about EC 2000's demise. Some of the leaders of ASEE ${ }^{63}$ thought we could convince our peers in other professional engineering societies or disciplinary departments to adopt active learning and 
other best practices if only we could produce 'hard' evidence that these practices work, that these educational interventions are effective.

Ironically, the perception that some outcomes are "difficult to assess" has not been subjected to the same standards of evidence purported to be valued by ABET.

In buying into their epistemic terms, in letting others define the question, "what works?," we have chosen to consider measurable only that which fits one narrow framework for evidence. Implicit in this move is a devaluing of the epistemic frames upon which the eliminated outcomes are based; global and social context, professional responsibility, and lifelong learning are not fully characterized by empirical and logical positivist ways of knowing. We need multiple epistemic frames both for our students to meet the full set of engineering learning outcomes, and to adequately assess student achievement of them.

Education scholar Gert Biesta ${ }^{64}$ argues that "what works?" is the wrong question because it precludes the question "what ought to be learned?" He suggests that over-attention to what is effective in evidence-based logic has caused us to lose sight of what is appropriate.

In previous work ${ }^{2}$ I have pointed out the troubling pedagogical implications of evidence-based practice. The medical model assumes that a treatment causes an effect, which is then measured quantitatively. But Biesta notes that this is an exceedingly reductionist view of education in which students are robbed of all agency, where they become completely passive receptacles of knowledge. On the contrary, Biesta asserts:

If teaching is to have any effect on learning, it is because of the fact that students interpret and try to make sense of what they are being taught. It is only through processes of (mutual) interpretation that education is possible. ${ }^{64}(8)$

In a learner-centered rather than outcome-centered environment, assessment would take a very different form, where students would necessarily take an active role in it. ${ }^{65}$

\section{The Business of ABET}

In addition to understanding these changes as the logical outcomes of evidence-based practice and outcomes-based assessment, we might ask structural questions about the economic function of ABET as a non-profit organization in the larger engineering education ecosystem, or in the larger accreditation ecosystem, which faces its own set of political and economic pressures. Some critics who study the K-12 landscape have written about the problematic financial interests underlying the school reform movement, where private companies are developing both the curriculum and the tests to support and measure the achievement of standards imposed by states under No Child Left Behind, Race to the Top, and other policy initiatives. Perversely, these companies benefit from ever-failing schools and an ever-changing landscape of standards, because they can rewrite the curricula and design and administer the new tests. They thereby expand their market. ${ }^{66}$ Over the past decade some have advocated extending these models to higher education. 
We might then ask whether and how ABET stands to benefit as an organization from its proposed changes. We know that institutions pay tens of thousands of dollars to evaluate their suite of engineering degree programs every six years (or more often). ABET's status as a not-forprofit corporation does not eliminate its need for steady income streams. When institutions grumble about assessment burden and wonder if accreditation is "worth it," what kinds of financial repercussions follow? What economic and political forces drive ABET's international expansion, and how might those interests converge with the proposed criteria changes? These questions are merely suggestive, but it will be important to fully grapple with the business of ABET in order to understand the meaning of these proposed changes for engineering education in the United States and worldwide.

\section{The Long Haul}

Where does all of this leave those of us concerned with the broad education of engineers? An opaque process has produced sweeping changes based on flimsy rationales that threaten to gut educational breadth for engineers. These changes are in some ways the predictable product of outcomes-based assessment and an over-emphasis on narrow "evidence-based" practice, played out in the broader economic and political landscapes of education and assessment.

Educator Myles Horton, ${ }^{67}$ developer of popular education, spoke eloquently of the "long haul" for advocates of more accessible, more just, and more holistic forms of education (and other social systems). Indeed the history of the Liberal Education/Engineering and Society Division in ASEE reveals patterns ${ }^{15}$ over the last century of calls for engineers with educational breadth and skills in communication, ethics, teamwork, multicultural competencies, and so much more - and the profession's failure time and again to produce engineers with these capabilities.

We will surely continue to be in this struggle for the long haul. Now is the time for us (once again) to organize, to build coalitions, and to leverage all of our social analytical ability toward the effort of winning hearts and minds in support of the broad education of engineers. What appeared to be consensus over EC2000 is now revealed to have been fragile at best, and we must work to strengthen and re-build this movement.

\section{LEES as Clearinghouse with Convening Power}

In recent years LEES has led ASEE in building relationships across divisions, initiating and sustaining a series of interdivisional Town Halls, and greater collaboration across divisions in programming at conferences as well as stronger engagement with policy changes like those proposed by ABET. LEES Chair Steve VanderLeest convened the interdivisional Ad Hoc Committee on ABET Changes that organized Webinars to inform ASEE members and solicit feedback, which informs the Town Hall at the 2016 ASEE on ABET's proposed changes. LEES is the intellectual home for scholars focused not on ABET per se but on the project of liberal education of engineers, and shaping engineering as a liberal arts discipline. LEES can provide the structure to archive the many and varied efforts in this arena, and begin to convene coalitions across professional societies. 


\section{Reclaiming ASEE's Expertise}

Historians in LEES have pointed out that ASEE used to control engineering accreditation, While it may be impossible to return to that arrangement, it is clear that the expertise of ASEE members, on the issue of assessment in particular, but also on education generally, is highly relevant and underutilized within ABET. Structural changes are needed that provide a distinct role for ASEE's expertise.

\section{LEES-Certified Programs}

Should the changes ABET currently has on the table be adopted, it may be necessary to devise a separate credentialing system that certifies programs that produce graduates with broad educations and professional skills. At first blush this sounds like a lot of work, possible more than our Division could take on. However, if we produced a straightforward, common-sense process that did not require the resources of time and energy that ABET currently demands (perhaps on the scale of the NAE Grand Challenge Scholars Program, or even directly building upon that effort), it is likely to be attractive to institutions and could in time supplant ABET accreditation at some institutions.

\section{Reconceptualize Assessment}

Such an effort would necessarily reconceptualize assessment. It would know, with Dewey, that "No conclusion of scientific research can be converted into an immediate rule of educational art"(19).$^{68}$ Rather than predicating a system on the notion of knowledge as information to be deposited in students' brains, Biesta ${ }^{64}$ draws on Dewey to propose an action-theoretical framework where the self is not held separate from the knowable world, where knowing is a form of doing, and reflection on experience brings about learning. Learning and assessment become one and the same in a learner-centered assessment environment. ${ }^{65}$

\section{Conclusion}

We assess what we value. The proposed changes to ABET Criteria 3 and 5 reveal that the consensus that leaders like Duderstadt, Wulf, Vest, Watson, Rogers, Prados and so many others worked tirelessly to build has fallen apart. We need strong leadership to assert once again the broad social purpose, ideals, and goals of the profession, and how education ought to be guided by those values. The LEES Division has a strong leadership role to play in convening and cultivating this leadership, in organizing and building relationships that help us to once again change hearts and minds about the importance of a liberal education for engineers.

\section{Acknowledgments}

The Ad Hoc Group on ABET Changes convened by LEES Chair Steve VanderLeest and the authors of AgainstABET.org contributed to the analysis of ABET changes presented here. 


\section{Appendix: ABET Criteria 3 and 5 Comparisons}

\section{EC 2000 Criterion 3}

(a) an ability to apply knowledge of mathematics, science, and engineering

(b) an ability to design and conduct experiments, as well as to analyze and interpret data

(c) an ability to design a system, component, or process to meet desired needs within realistic constraints such as economic, environmental, social, political, ethical, health and safety, manufacturability, and sustainability

(d) an ability to function on multidisciplinary teams

(e) an ability to identify, formulate, and solve engineering problems

(f) an understanding of professional and ethical responsibility

(g) an ability to communicate effectively

(h) the broad education necessary to understand the impact of engineering solutions in a global, economic, environmental, and societal context

(i) a recognition of the need for, and an ability to engage in life-long learning

(j) a knowledge of contemporary issues

(k) an ability to use the techniques, skills, and modern engineering tools necessary for engineering practice.

\section{Proposed Criterion 3 (1-7)}

1. An ability to identify, formulate, and solve engineering problems by applying principles of engineering, science, and mathematics.

2. An ability to apply both analysis and synthesis in the engineering design process, resulting in designs that meet desired needs.

3. An ability to develop and conduct appropriate experimentation, analyze and interpret data, and use engineering judgment to draw conclusions.

4. An ability to communicate effectively with a range of audiences.

5. An ability to recognize ethical and professional responsibilities in engineering situations and make informed judgments, which must consider the impact of engineering solutions in global, economic, environmental, and societal contexts.

6. An ability to recognize the ongoing need for additional knowledge and locate, evaluate, integrate, and apply this knowledge appropriately.

7. An ability to function effectively on teams that establish goals, plan tasks, meet deadlines, and analyze risk and uncertainty.

\section{Proposed Criterion 3 (1-6) (Version proposed 2014-15)}

1. An ability to use the principles of science and mathematics to identify, formulate and solve engineering problems.

2. An ability to apply both analysis and synthesis in the engineering design process, resulting in designs that meet constraints and specifications. Constraints and specifications include societal, economic, environmental, and other factors as appropriate to the design.

3. An ability to develop and conduct appropriate experimentation and testing procedures, and to analyze and draw conclusions from data.

4. An ability to communicate effectively with a range of audiences through various media.

5. An ability to demonstrate ethical principles in an engineering context.

6. An ability to establish goals, plan tasks, meet deadlines, manage risk and uncertainty, and function effectively on teams. 


\section{EC 2000 Criterion 5}

The faculty must ensure that the program curriculum devotes adequate attention and time to each component, consistent with the outcomes and objectives of the program and institution. The professional component must include:

(a) one year of a combination of college level mathematics and basic sciences (some with experimental experience) appropriate to the discipline. Basic sciences are defined as biological, chemical, and physical sciences.

(b) one and one-half years of engineering topics, consisting of engineering sciences and engineering design appropriate to the student's field of study. The engineering sciences have their roots in mathematics and basic sciences but carry knowledge further toward creative application. These studies provide a bridge between mathematics and basic sciences on the one hand and engineering practice on the other. Engineering design is the process of devising a system, component, or process to meet desired needs. It is a decisionmaking process (often iterative), in which the basic sciences, mathematics, and the engineering sciences are applied to convert resources optimally to meet these stated needs.

(c) a general education component that complements the technical content of the curriculum and is consistent with the program and institution objectives.

\section{Proposed Criterion 5}

The curriculum requirements specify subject areas appropriate to engineering but do not prescribe specific courses. The curriculum must support attainment of the student outcomes and must include:

(a) one academic year of a combination of college-level mathematics and basic sciences (some with experimental experience) appropriate to the program.

(b) one and one-half academic years of engineering topics, consisting of engineering sciences and engineering design appropriate to the program and utilizing modern engineering tools.

(c) a broad education component that includes humanities and social sciences, complements the technical content of the curriculum, and is consistent with the program educational objectives.

\section{References}

[1] Riley, D. (2012). Aiding and ABETing: The Bankruptcy of Outcomes-Based Education in Engineering. ASEE Annual Conference.

[2] Riley, D. (2014). What's Wrong with Evidence? Epistemological Roots and Pedagogical Implications of "Evidence-Based Practice" in STEM Education. ASEE Annual Conference.

[3] ABET Engineering Accreditation Commission (2015). Engineering Criteria 2000 (EC 2000), 2014-15. http://www.abet.org/wp-content/uploads/2015/04/E001-14-15-EAC-Criteria.pdf

[4] ABET Engineering Accreditation Commission (2015). ABET History.http://www.abet.org/about-abet/history/.

[5] Prados, J.W. (1992). Quality and Innovation in Engineering Education: 1991-92 ABET President's Report. Washington, DC: Accreditation Board on Engineering and Technology.

[6] ABET Engineering Accreditation Commission (April 2015). EAC Proposed Revisions to Criteria 3 and 5. Washington, DC: ABET, Inc.. Accessed June 2015 from http://www.abet.org/wpcontent/uploads/2015/04/EAC-Proposed-Revisions-to-Criteria-3-and-5.pdf.

[7] Mann, C.R. (1918). A Study of Engineering Education: Prepared for the Joint Committee on Engineering Education of the National Engineering Societies. Boston: Merrymount. http://web.mit.edu/ jwk/www/docs/Mann\%201918\%20Study_of_Engineering_Educ.pdf 
[8] Wickenden, W.E. (1930) Report of the Investigation of Engineering Education, 1923-1929, vol. I. Pittsburgh: Society for the Promotion of Engineering Education.

[9] Hammond, H.P. (1946). Report on humanistic social studies in engineering education. Journal of Engineering Education 36 (January): 338-351.

[10] Grinter, L.E. (1956). Report on the evaluation of engineering education. Journal of Engineering Education, 46: 25-63.

[11] NAE (2004). The Engineer of 2020: Visions of Engineering in the New Century. Washington, DC: The National Academies Press.

[12] NAE (2005). Educating the Engineer of 2020: Adapting Engineering Education to the New Century. Washington, DC: National Academies Press.

[13] ASEE. (2013). Transforming Undergraduate Engineering Education: Phase I Workshop Report. Washington, DC: American Society for Engineering Education. https://www.asee.org/TUEE_PhaseI_WorkshopReport.pdf

[14] International Engineering Alliance. (2013). Graduate Attributes and Professional Competencies. http://www.ieagreements.org/IEA-Grad-Attr-Prof-Competencies.pdf.

[15] Seely, B. (2005). Patterns in the History of Engineering Education Reform: A Brief Essay. In Educating the Engineer of 2020: Adapting Engineering Education to the New Century. Washington, DC: National Academies Press, 2005, pp. 114-30.

[16] Lattuca, L.R., Terenzini, P.T., Volkwein, J.F., and Peterson, G.D. The Changing Face of Engineering Education. The Bridge, Summer 2006. http://www.nae.edu/Publications/Bridge/ReformingEngineeringEducation/TheChangingFaceofEngineeringEdu cation.aspx.

[17] Atman, C., Jamieson, L., Turns, J., and Riley, D. et al. (2015). Please extend the comment period for proposed changes to ABET Criterion 3. Personal Communication, June 30, 2015.

[18] VanderLeest, S., Nieusma, D., Brocato, J., Cotter, S., Apidone, G. and Akera, A. (2015). ASEE Liberal Education/Engineering and Society Division Comments on Proposed Changes to Criteria 3 and 5. June 24, 2015. https://docs.google.com/viewer?a=v\&pid=sites\&srcid=ZGVmYXVsdGRvbWFpbnxhc2VlbGVlc3xneDo2YmQ 2YWQzZWI0ZDcwY2Fl.

[19] Bates, B. (2015). Personal Communication. July 2015.

[20] Mina, M. (2015). Concerning ABET Changes. Personal Communication. June 25, 2015.

[21] Minerick, A. (2015). Comments RE Criterion 3 and 5; Suggested New Outcome on Diversity and Inclusion. Personal Communication. July 6, 2015.

[22] ABET Engineering Accreditation Commission (November 2015). EAC Proposed Revisions to Criteria 3 and 5. Washington, DC: ABET, Inc.. Accessed from http://www.abet.org/wp-content/uploads/2015/11/ProposedRevisions-to-EAC-Criteria-3-and-5.pdf

[23] ABET Engineering Accreditation Commission (November 2015). Rationale for Revising Criteria 3 and 5. Washington, DC: ABET, Inc.. Accessed from http://www.abet.org/accreditation/accreditationcriteria/accreditation-alerts/rationale-for-revising-criteria-3/

[24] Shuman, L.J., Besterfield-Sacre, M. and McGourty, J. (2005). The ABET 'Professional Skills' - Can they be Taught? Can they be Assessed? Journal of Engineering Education, 94(2): 41 - 55.

[25] Besterfield-Sacre, M. and Shuman, L.J. (2008). The Future of Assessment. In: Designing Better Engineering Education Through Assessment: A Practical Resource for Faculty and Department Chairs on Using Assessment and ABET Criteria to Improve Student Learning, edited by Spurlin, J., Rajala, S., \& Lavelle, J., 307-327. Sterling, Va: Stylus Publishing.

[26] Riley, D.M. and Claris, L. Developing and Assessing Students' Capacity for Lifelong Learning. International Journal of Engineering Education 24 (5): 906-916, 2008.

[27 Pappas, E.C., S.L. Kampe, R.W. Hendricks, and R.G. Kander. (2004). An Assessment Analysis Methodology and its Application to an Advanced Engineering Communications Program. Journal of Engineering Education, 93 (3): 233-246. 
[28] Davis, D. C., Gentili, K. L., Trevisan, M. S. and Calkins, D. E. (2002). Engineering Design Assessment Processes and Scoring Scales for Program Improvement and Accountability. Journal of Engineering Education, 91: 211-221.

[29] Ro, H. K., Merson, D., Lattuca, L. R. and Terenzini, P. T. (2015), Validity of the Contextual Competence Scale for Engineering Students. Journal of Engineering Education, 104: 35-54.

[30] Using "ABET Assessment" as a search term in JEE produces nearly 300 articles, and in the ASEE Proceedings database, over 5000, speaking to the vibrancy of this research area.

[31] ABET. (2007). Best Assessment Practices Symposium IX. http://dev.rose-hulman.edu/assessment2007/

[32] Palomba, C. and Banta, T. (2015). Assessment Essentials: Planning, Implementing, and Improving Assessment in Higher Education. 2nd Edition. New York: Wiley.

[33] Silbey, S.S. and Seron, C. (2009). The Dialectic between Expert Knowledge and Professional Discretion: Accreditation, Social Control and the Limits of Instrumental Logic. Engineering Studies, 1(2):101-127.

[34] Cameron, W.B. (1963). Informal Sociology: A Casual Introduction to Sociological Thinking. New York: Random House, p. 13.

[35] Akera, A. (2016). [Paper in this Conference - will update title when available.]

[36] Casey, S. M. (1998). Set Phasers on Stun: And Other True Tales of Design, Technology, and Human Error. Santa Barbara: Aegean.

[37] Casey, S. M. (2006). The Atomic Chef: And Other True Tales of Design, Technology, and Human Error. Santa Barbara, CA: Aegean.

[38] Foucault, M. (1980). Power/Knowledge: Selected Interviews and Other Writings, 1972-1977. (C. Gordon, Ed.) New York: Vintage.

[39] Dewey, J. (1933) How we think: a restatement of the relation of reflective thinking to the educative process. Boston: D.C. Heath.

[40] Freire, P. (1971). Pedagogy of the Oppressed. M. Bergman Ramos, trans. New York: Continuum.

[41] Dewey, J. (1938). Experience and Education. New York: Macmillan.

[42] Claris, L. and Riley, D. Situation Critical: Critical Theory and Critical Thinking in Engineering Education. Engineering Studies, 4(2): 101-120, 2012.

[43] Mead, L.M. (2013). Teaching Public Policy: Linking Policy and Politics. Journal of Public Affairs Education, 19(3): 389-403.

[44] Winner, L. (1980). Do Artifacts Have Politics? Daedalus, 109(1): 121-136.

[45] Noble, D. F. (1979). America by Design: Science, Technology, and the Rise of Corporate Capitalism. Oxford: Oxford University Press.

[46] Cech, Erin A. and Heidi M. Sherick. (2015). "Depoliticization and the Structure of Engineering Education." In International Perspectives on Engineering Education, S. H. Christensen et al. eds. New York: Springer. pp. 203-216.

[47] Giddens, A., Duneier, M., Appelbaum, R. P., \& Carr, D. (2013). Introduction to Sociology (9th ed.). New York: W. W. Norton \& Company.

[48]Harris, C. E., Pritchard, M.S. and Rabins, M.J. (2005) Engineering Ethics: Concepts and Cases. $3^{\text {rd }}$ ed. Stamford, CT: Thomson Wadsworth.

[49] Adams, W.M. (2006). "The Future of Sustainability: Re-thinking Environment and Development in the Twentyfirst Century." Report of the IUCN Renowned Thinkers Meeting, 29-31 January 2006.

http://cmsdata.iucn.org/downloads/iucn_future_of_sustanability.pdf.

[50] Drum, K. (2015). Volkswagen's Emissions Conspiracy May Have Killed at Least 4,000 People Worldwide. Mother Jones, September 24, 2015. http://www.motherjones.com/kevin-drum/2015/09/spreadsheet-day-howmany-people-did-vw-kill

[51] Baillie, C. (2014) Interview with Maxima Acuña de Chaupe, Cajamarca Peru, October 2014. https://vimeo.com/122399156. 
[52] Kaffer, N. (2015). MDEQ e-mails show stunning indifference to Flint peril. Detroit Free Press, Oct. 22, 2015. http://www.freep.com/story/opinion/columnists/nancy-kaffer/2015/10/21/indifference-characterized-stateapproach-flint-water/74289430/.

[53]Pinch, T.J. and Bijker, W.E. (1984). The Social Construction of Facts and Artefacts: Or How the Sociology of Science and the Sociology of Technology Might Benefit Each Other. Social Studies of Science 14: 399-441.

[54] Ford, J. D. and Riley, L. A. (2003), Integrating Communication and Engineering Education: A Look at Curricula, Courses, and Support Systems. Journal of Engineering Education, 92: 325-328.

[55] Wilczynski, V. and Douglas, S. M. (1995), Integrating Design Across the Engineering Curriculum: A Report From the Trenches. Journal of Engineering Education, 84: 235-240.

[56] Davis, M. (1993). Ethics Across the Curriculum: Teaching Professional Responsibility in Technical Courses. Teaching Philosophy, 16: 205-235.

[57] Katz, D. (1964), The motivational basis of organizational behavior. Systems Research, 9: 131-146.

[58] Henderson, C., Beach, A. and Finkelstein, N. (2011), Facilitating change in undergraduate STEM instructional practices: An analytic review of the literature. J. Res. Sci. Teach., 48: 952-984.

[59] Spady, W.G. (1994). Outcome Based Education: Critical Issues and Answers. Arlington, VA: American Association of School Administrators.

[60] Lorenzen, M. (1999). Using Outcome-Based Education in the Planning and Teaching of New Information Technologies. Journal of Library Administration, 26 (3-4): 141-52.

[61] Bennett, W.J. (1986). What Works: Research about Teaching and Learning. Washington, D.C.: U.S. Department of Education.

[62] Olson, D. (2004). The triumph of hope over experience in the search for "what works": A response to Slavin. Educational Researcher, 33(1): 24-26.

[63] Jamieson, L. and Lohmann, J. (2012). Innovation with Impact: Creating a Culture for Scholarly and Systematic Innovation in Engineering Education. Washington, DC: ASEE. https://www.asee.org/memberresources/reports/Innovation-with-Impact

[64]Biesta, G. (2007). Why “what works” won't work: Evidence-based practice and the democratic deficit in educational research. Educational Theory. 57(1):1-22.

[65]Riley, D. M., Claris, L., Paul-Schultz, N. and Ngambeki, I. Learning/Assessment: A tool for assessing liberative pedagogies in engineering education. ASEE Annual Conference Proceedings, June 18 - 21, Chicago, IL (2006).

[66] Junemann, C. and Ball, S.J. (2015). Pearson and PALF: The Mutating Giant. Brussels, Belgium: Education International. http://download.ei-ie.org/Docs/WebDepot/ei_palf_publication_web_pages_01072015.pdf

[67]Horton, M., \& Kohl, J. and H. (1997). The Long Haul: An Autobiography. New York: Teachers College Press.

[68] Dewey, J. (1929). The sources of a science of education. New York: Horace Liverlight. 